\title{
MAKING MOUNTAINS OF DEBT OUT OF MOLEHILLS: THE PRO-CYCLICAL IMPLICATIONS OF TAX AND EXPENDITURE LIMITATIONS
}

\section{Mathew D. McCubbins and Ellen Moule}

This paper presents evidence that property tax limits have detrimental effects on state and local revenues during recessions. Property tax limits cause states to rely on income-elastic revenue sources, such as the income tax or charges and fees. Greater reliance on these revenue sources results in greater revenue declines during economic downturns. We present analysis of timeseries, cross-sectional data for the U.S. states for each of these conclusions. Our results suggest that states would have fewer and more modest financial problems during economic downturns if they did not enact property tax limitations.

Keywords: tax and expenditure limits, tax elasticity, state and local revenue policy JEL Codes: H20, H71

Mathew D. McCubbins: Provost Professor of Business, Law and Political Economy, University of Southern California, Los Angeles, CA, USA (mmccubbins@marshall.usc.edu)

Ellen Moule: Graduate Student, UC San Diego Department of Political Science, San Diego, CA, USA (emoule@ucsd.edu) 


\section{Introduction}

In this paper we analyze the effect of property tax limitations on state and local revenue during economic recessions. We argue that the changes to revenue policy precipitated by property tax limits cause short-term instability during fiscal crises. Our work continues a string of research that argues that fiscal limitations often have unintended secondary and tertiary consequences. Instead of cutting the size of government, scholars have shown that public officials almost always find ways to circumvent the spirit of most taxing, spending, and deficit limitations (Kiewiet and Szakaty 1996, Gerber et al. 2001, Kousser, McCubbins, Moule 2008). For example, if a limit only restricts property taxes, a locality might switch to revenues derived from charges and fees or sales taxes. Likewise, if a revenue limit only restricts state revenues, a hike in property tax collections at the local level might ensue. These evasion techniques, while increasing government size, allow public officials to abide by the letter of the law. This paper analyzes the tertiary consequences of these actions.

Despite these known evasiation tactics, the complaints of politicians regarding the bite of voter proscribed revenue limitations are especially shrill during recessions. We consider the hypothesis that tax caps lead to greater short-term declines in revenue during recessions than would otherwise occur in the absence of these caps. We posit that property tax limits and the politics of circumvention that they engender have a tertiary effect, aggravating the effects of public economic crises. Specifically, we argue that tax revolt legislation has led state and local governments to rely on sources of revenue that are increasingly elastic with respect to changes in personal income. These new revenue sources are less stable during recessions than the previous 
mainstay of state and local government revenue, the property tax. As a result, state and local revenues are more pro-cyclical, they grow quickly during economic booms and crash during recessions.

This paper tests the hypothesis that property tax limits aggravate revenue declines during fiscal crises by analyzing time-series, cross-sectional data for the U.S. States. During the time frame analyzed in this paper, all fifty states experienced multiple economic declines. For the purposes of our test it is especially useful that the states do not suffer downturns at the same time and are not subject to property tax limits at the same time. This wide array of variation allows us to estimate the interaction affect between property tax limits and recessions. Our results support the hypothesis that property tax limits aggravate revenue declines in state and local governments during recessions. This suggests that states would have fewer and more modest financial problems during economic downturns if they did not enact tax limitations.

This paper proceeds in five parts. We start by describing the data used throughout this paper. We then review the previous literature with respect to the consequences of property tax limits on government revenue streams. We then reinforce two findings in the literature, showing that property tax limits lead to increases in income taxes and the assessments of charges and fees. In the section that follows, we tie these consequences with what is known about revenue stability during fiscal downturns from the public finance literature. In particular, we show that state income taxes, charges and fees have a relatively high income-elasticity. Next, we present a model of the effect of property tax limits, recessions, and their interaction. In so doing, we conclude that property tax limits aggravate revenue declines during recessions. In the final section we summarize our conclusions. 


\section{Data}

We start by describing the data used in all statistical analyses in this paper. Our key independent (i.e., treatment) variable is an indicator for the presence of a property tax limit (see Table 1). The following rules were used to determine the existence of a property tax limit. First, the limit must restrict property taxes for all geographic areas of the state (no local options). Second, if the limit does not restrict all taxing entities (e.g., it only limits municipalities but not special districts), then constrained taxing entities must collect a majority of the state's property taxes. Third, the limit must be either a revenue limit (pegging increases in total property tax revenues to an explicit rule) or it must stipulate both a tax rate limit and cap the growth of assessed property values simultaneously. This last rule means that states that have assessment limits but not tax rate limits are excluded from consideration. The tax limit indicator is coded as one in a fiscal year if a state has an active property tax limit and zero otherwise. It is noteworthy that several states have repealed their tax limits over our time series. 
Table 1

Statewide Property Tax Limits in the US

\begin{tabular}{|c|c|}
\hline State & Years Implemented \\
\hline Arizona & 1981-Present \\
\hline Arkansas & 1982-Present \\
\hline California & 1979-Present \\
\hline Colorado & 1993-Present \\
\hline Florida & 1995-Present \\
\hline Idaho & 1980-1992, 1996-Present \\
\hline Indiana & 1980-Present \\
\hline Kansas & 1986-1998 \\
\hline Kentucky & 1980-Present \\
\hline Maine & 2006-Present \\
\hline Massachusetts & 1982-Present \\
\hline Michigan & 1979-Present \\
\hline Missouri & 1981-Present \\
\hline Montana & 1987-Present \\
\hline Nevada & 1984-Present \\
\hline New Mexico & 1980-Present \\
\hline Oklahoma & 1997-Present \\
\hline Oregon & Start-Present \\
\hline South Dakota & 1997-Present \\
\hline Utah & Start-1986 \\
\hline Washington & 1974-Present \\
\hline West Virginia & 1991-Present \\
\hline Iowa & 1979-Present \\
\hline Louisiana & 1979-Present \\
\hline Wisconsin & 2006-Present \\
\hline Mississippi & 1995-Present \\
\hline
\end{tabular}

We collected a variety of covariates standard in the state and local finance literature to control for other factors that affect revenue collections. Specifically, we generally control for three measures of population fluctuation: total population, elderly population (as defined by the number of individuals over the age of 65), and school-age population (this group was approximated using the age category 5-19). Each of these variables was collected from annual 
estimates of statewide residents by the Census Bureau. We also control for state political characteristics using a set of dummy variables that indicate the existence of unified Republican government, unified Democratic government, or divided government (c.f. Alt and Lowry 1994, 2000). For modeling purposes, divided government is omitted and used as the reference group for the two other dummy variables. Finally, we control for state personal income and statewide total employment to hold constant changes in the economy. Both of these variables were collected from the Bureau of Economic Analysis. Descriptive statistics for these variables and others appear in Table 2.

Table 2

Summary Statistics: 49 states (Alaska Excluded), 1980-2000

\begin{tabular}{lllll}
\hline Variable & Mean & Std. Dev. & Min & Max \\
\hline Percent Income Taxes & 16.28 & 8.20 & 0 & 32.88 \\
Percent Sales Taxes & 25.43 & 8.22 & 5.16 & 45.71 \\
Percent Charges and Fees & 30.91 & 5.41 & 16.71 & 53.90 \\
Percent Property Taxes & 20.93 & 7.61 & 5.70 & 50.47 \\
& & & & \\
School Age Population (million) & 1.12 & 1.18 & 0.11 & 7.65 \\
Elderly Population (milions) & 0.63 & 0.66 & 0.04 & 3.56 \\
Total Population (millions) & 5.12 & 5.45 & 0.45 & 33.50 \\
Total Employment (millions) & 2.72 & 2.88 & 0.26 & 18.50 \\
Personal Income (millions) & 151.3 & 177.3 & 11.1 & 1216.2 \\
Unified Republican Control & 0.30 & 0.46 & 0 & 1 \\
Unified Democratic Control & 0.16 & 0.36 & 0 & 1 \\
& & & & \\
General Revenue Growth $(\Delta \mathrm{LN})$ & 0.03 & 0.04 & -0.16 & 0.22 \\
Recession Indicator & 0.36 & 0.48 & 0 & 1 \\
\hline
\end{tabular}

Another variable used in some of our analysis is a measure of state recessions. Our data here comes from work by Owyang, Piger, and Wall (2005). These authors produce data that measures the number of quarters per calendar year that each of the fifty states should be 
classified as being in recession between fiscal years 1980-2001. We use this data to create an annual indicator of state recessions. Specifically, we classify a state as being in recession if at least three quarters of its fiscal year have a recession probability greater than $0.5{ }^{1}$

Owyang, Piger, and Wall (2005) estimate state recession probabilities quarterly for each of the fifty states from 1980-2001 using the Markov-switching model developed by Hamilton (1989). Hamilton's method estimates endogenously the timing of shifts from expansion to contraction of the economy. This model estimates when the mean growth rate switches between high and low growth regimes. ${ }^{2}$ This estimation procedure produces recession probabilities, ranging from zero to one that represent the probability that a state is in a recession in a given quarter. In this paper we rely on a simple cut-off method to identify whether or not a quarter can be classified as in a recession. If the recession probability is greater than 0.5 during any given quarter, a state is coded as being in recession for that quarter. This cut-off rule is noncontroversial as Owyang, Piger, and Wall (2005) report that recession probabilities are regularly either close to zero or close to one.

Finally, the dependent variables in all analysis are measures of state and local fiscal

\footnotetext{
${ }^{1}$ The cut-off of at least three quarters in recession was chosen through a non-parametric estimate of the affect of each additional quarter of recession on general revenues. The results of this estimation showed that a state must have three or four quarters of recession to see a statistically significant decline in general revenues. The size of the coefficients for three and four quarters were statistically indistinguishable, suggesting that a dummy variable specification of this variable is superior to a count variable that assumes a linear relationship between revenue outcomes and the numbers of quarters in recession.

${ }^{2}$ The underlying data used to calculate recession probabilities is a state-level coincident index by Crone (2002). Crone's widely used index follows the methodology developed by Stock and Watson (1989) for the national economy. Crone uses three monthly and one quarterly economic indicator to estimate the underlying state of the economy. These indicators are nonagricultural payroll employment, unemployment rate, average hours worked in manufacturing, and real wage and salary disbursements. This data is preferable to other economic indicators because it displays substantial business cycle variability (unlike personal income) and is available on a quarterly basis (unlike gross state product) for each state.
} 
behavior. We rely on data from the Commerce department's publication of Annual State and Local Government finances. The variables included in our analysis are state and local general own-sources revenues, income taxes, sales taxes, property taxes, and charges and fees. The exact specification of each of these variables will be detailed in the discussions of research design that precede all statistical analyses.

\section{The Consequences of Property Tax Limits on Government Revenues}

In this section we review previous findings on the secondary consequences of property tax limits. Before the tax revolt even ended, newspaper columnists and policy experts immediately identified ways in which property tax limitations would change government fiscal structure. Since then, empirical tests have confirmed many of these speculations (Danziger and Ring 1982; Joyce and Mullins 1991; Mullins and Joyce 1996; Kousser, McCubbins, Moule 2008). Specifically, property tax limits increase a state's reliance on charges and fees, sales taxes, income taxes, and the use of off-budget activities (Bennet and DiLorenzo 1982, Schwartz 1997, Thompson and Green 2004).

A significant conclusion of the previous literature is that property tax limits lead to increases in income and sales taxes. Specifically, Thompson and Green (2004) show that Oregon's property tax limit prompted the state to rely more heavily on income taxes. Skidmore (1999), using data from all fifty states, show that local government restrictions lead to growth in state aid to local governments. This is clearly the case in Massachusetts. Increases in state aid occurred immediately after the adoption of their property tax limit, Proposition $2 \frac{1}{2}$. Though this increase was initially sustained by a strong economy, the so-called "Massachusetts Miracle", the 
state was later forced to raise the flat rate personal income tax to sustain high levels of state aid.

By contrast, increases in the use of the sales taxes were evident in California. Several scholars have argued that localities have been turned into "sales-tax farms", affecting redevelopment, zoning, and eminent domain, favoring car dealerships and significant shopping malls over mom-and-pop businesses. This activity even garnered a name, the "fiscalization of land use." (Schwartz 1997; Lewis 2001)

There is also strong evidence that property tax limits increase assessments of charges and fees. Charges and fees are assessed in a variety of forms: increases in college tuition, business licenses and fees, charges for school lunches, park fees, impact fees, or costs associated with public parking. Many property tax bills today are now loaded with "special assessments" in lieu of ad valorem property taxes (Kogan and McCubbins 2009). Sometimes, the assessment of charges in fees instead of property taxes is a simple case of substitution: water bills that were once subsidized by local government property taxes and now paid for in full directly by the user in the form of standby charges or sewerage fees (Moule 2010).

Alternatively, charges and fees can also be a consequence of changes to the structure of government. Previous research suggests that property tax limits splinter government revenue sources. Instead of classic budgetary procedures where the whole of government spending is allocated from general revenue sources, property tax limits led to the creation of special funds and devolve finances to newly formed special districts or enterprises. Bennet and DiLorenzo's (1982) early work on this subject posited that property tax limits led to a "massive amount of off-budget spending and borrowing". In particular, Bennet and DiLorenzo were concerned with the proliferation of "off-budget enterprises", the political entities referred to as authorities, 
districts, commissions, or agencies. Most recently, Bowler and Donovan (2004) found that property tax limits were the cause of special district formation, at least in states that heavily used the initiative process. Special districts and the like, given their purpose of service delivery, are likely to rely on user-fees instead of traditional taxes.

To bolster and systemize this evidence, we conduct our own test of whether or not property tax limits increase reliance on sales taxes, income taxes, and charges and fees. We rely on a differences-in-differences model (c.f. Wooldridge 2006) to estimate the effect of property tax limits on the relative usage of each revenue stream. This model allows us to hold constant unobserved, time-invariant state-level characteristics that predict state and local revenues. Additionally, this model controls for variation of the dependent variable related only to the passage of time that is constant across all states.

Our dependent variables are constructed as the specific revenue stream (charges and fees, sales taxes, income taxes, and property taxes) as a proportion of general own-source revenues. Because the errors across these equations are likely to be correlated, we employ a seemingly unrelated regression model (Zellner 1962). This model shows statistically significant negative correlation in the error terms between each revenue source, as one would expect in when these taxes are substitutes for each other.

Measuring these variables as a proportion of general revenues relieves some of the pernicious autocorrelation that often concerns analysis of fiscal outcomes in differences-indifferences analysis (Bertrand 2004). As an added precaution, however, we present results for a limited subset of data. Specifically, the analysis that follows only includes data for every fifth year starting in 1977. This method is preferable to first differencing, another affective way of 
removing serial correlation, in this instance because we are able to retain our dependent variable in levels, as opposed to changes. Our hypothesis predicts that property tax limits will affect the level of reliance on each revenue stream. Using every fifth year of data only slightly attenuates the significance of our findings.

We regress our dependent variables on an indicator for property tax limits as well as an array of covariates and state and year fixed effects. Our model is estimated by (1):

$$
Y_{i t}=\beta_{o}+\beta_{1} \mathrm{~T}_{i t}+\beta_{2} \theta_{i t}+\kappa_{t}+a_{i}+u_{i t}
$$

Where:

$\mathrm{y}=$ fiscal outcome as a proprtion of general, own-source revenues

$\mathrm{T}=$ indicator a property tax limit

$\theta=$ Covariates

$\kappa=$ Year fixed effects

$\mathrm{a}=$ State fixed effects

\section{Table 3}

Affect of Property Tax limits on Revenue Components

\begin{tabular}{lllll}
\hline & Charges and Fees & Income Taxes & Property Taxes & Sales Taxes \\
\hline Property Tax Limit & $0.823(0.443)^{*}$ & $0.912(0.425)^{* *}$ & $-1.666(0.437)^{* * *}$ & $-0.094(0.488)$ \\
School Age Population & $0.425(1.960)$ & $-0.938(1.881)$ & $-1.574(1.930)$ & $0.376(2.158)$ \\
Elderly Population & $3.439(3.308)$ & $-4.643(3.174)$ & $7.322(3.258)^{* *}$ & $-5.314(3.642)$ \\
Total Population & $-0.509(1.109)$ & $-0.414(1.064)$ & $2.448(1.092)^{* *}$ & $-0.17(1.221)$ \\
Employment & $-1.316(1.348)$ & $1.697(1.293)$ & $-4.925(1.327)^{* * *}$ & $3.792(1.484)^{* *}$ \\
Personal Income & $0.022(0.010)^{* *}$ & $-0.003(0.009)$ & $0.002(0.009)$ & $-0.034(0.011)^{* * *}$ \\
Unified Democratic Control & $0.637(0.404)$ & $-0.706(0.388)^{*}$ & $-0.0659(0.398)$ & $-0.371(0.445)$ \\
Unified Republic Control & $-0.185(0.295)$ & $-0.027(0.283)$ & $-0.31(0.291)$ & $0.682(0.325)^{* *}$ \\
Constant & $41.34(1.205)^{* * *}$ & $16.14(1.156)^{* * *}$ & $4.159(1.216)^{* * *}$ & $34.98(1.409)^{* * *}$ \\
\hline Observations & 294 & 294 & 294 & 294 \\
R-squared & 0.904 & 0.951 & 0.946 & 0.938 \\
\hline
\end{tabular}

Note: Estimated using seemingly unrelated regression. * signifies that the coefficient is significant at the .1 confidence level; ** at the .05 level; and *** at the .01 level. The dependent variables are state and local revenue components as a percentage of state and local general own-source revenue. Continous covariates are in millions. Years estimated are 1977, 1982, 1987, 1992, 1997, and 2002. Alaska is excluded.

The results of our estimation are displayed in Table 3. Each continuous covariate (total employment, personal income, and all population variables) is transformed to represent the effect 
of a million-unit change. As is clear from the table, however, the covariates generally do a poor job predicting reliance on each type of revenue stream, with the noticeable exception of the property tax.

As predicted the indicator for the presence of a property tax limit has noticeable effects on revenue choices. As intended, the adoption of a property tax limit decreases reliance on property taxes as a proportion of general revenues. Specifically, the adoption of a property tax limit is associated with approximately a 1.66 percentage point reduction of property taxes relative to general own-source revenues. In contrast, the adoption of a property tax limit is associated with increased reliance on both income taxes as well as the assessment of charges and fees (while the latter is not significant at conventional levels of confidence). Cumulatively, there is perfect substitution between declines in property taxes and increases in income taxes and charges and fees, as the latter increase 1.73 percentage points cumulatively. Finally, contrary to the previous literature, we find no statistically significant relationship between property tax limits and the sales tax in this model. 
Figure 1

Reliance on Revenue Sources, Before and After Property Tax Implementation

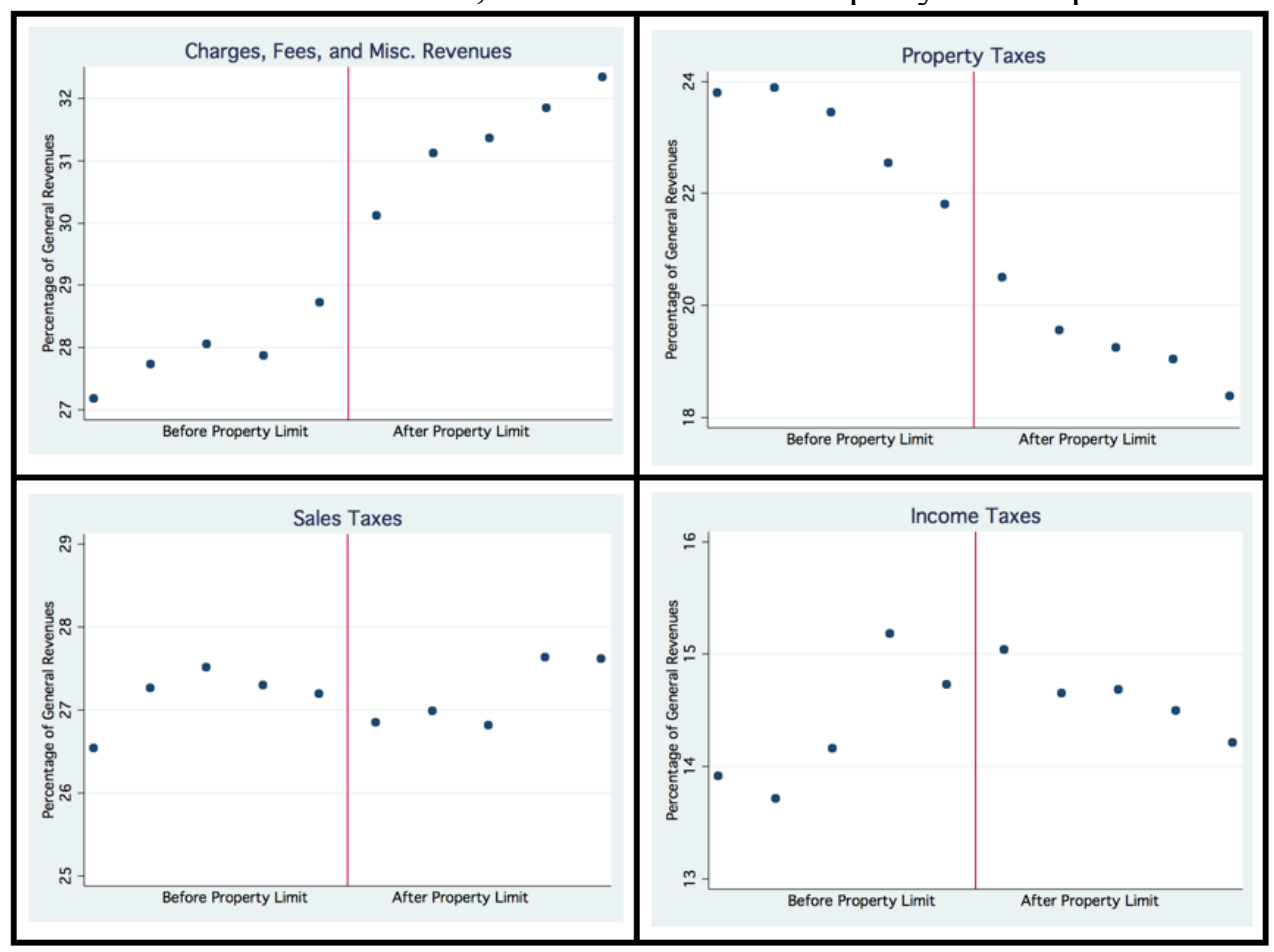

Figure 1 supports the statistical results. This figure presents four graphs, each showing average reliance on each revenue source five years before and five years after states implement property tax limits. States where data is not available for this full time-span are excluded (Maine, Wisconsin, Idaho, Oregon, Utah), as are states that never adopt limits. The vertical line in each figure represents the implementation of the limit. These figures show descriptively that property tax limits are associated with a decreased reliance on property taxes and increased reliance on charges and fees and to a lesser extent on income taxes. Again, there is no clear relationship with property tax limits and reliance on sales taxes.

Interestingly, the affect of property tax limits appears to occur shortly before the official implementation of the limit. This may mean that lawmakers change revenue policy in anticipation of TEL implementation, perhaps at the time when the limit is adopted. Another possibility is 
that the early changes in revenue policy are reflections of other events that are correlated with the adoption of property tax limits. This possibility led Kousser, McCubbins, Moule 2008 to conclude that TELs, by themselves, are not responsible for the declines in total state own-source revenue. For example, state legislatures commonly adopt property tax cuts or change assessment practices in an attempt preempt the passage of limits at the ballot box. Regardless of the exact timing, it is clear that property tax limits are significantly associated with changes to revenue policy. In the next section, we more thoroughly explain the implication of this consequence during fiscal downturns, turning financial molehills into mountains.

\section{Estimating Short-Run Revenue Stability}

We argue in this paper that shifts in revenue streams associated with property tax limitations have had deleterious affects on state financial health during recessions. Our conclusion is drawn from a literature in public finance that tells us that many of the new revenue sources that states rely on to replace lost property tax revenue are income-elastic. Research in public finance shows that income-elastic revenues lead to larger revenue growth in the long-run but are less stable in the short-run during a fiscal crisis.

The most comprehensive examination of short-term revenue instability during fiscal crises is by Holcombe and Sobel (1997). The authors present an error-correction model of tax elasticity. Elasticity refers to the responsiveness of revenues to changes in personal income. They find that corporate income taxes, personal income taxes, and non-food retail sales taxes are income-elastic whereas taxes on fuel usage and liquor sales are income-inelastic. Although they do not formally test the elasticity of property taxes (which is generally a local, not state revenue source), they 
characterize this revenue as "relatively stable over the business cycle." (Holcombe and Sobel 1997, p. 186). Looking at state-level data, Bruce, Fox, and Tuttle (2006) found that short-run income elasticity was greater for income taxes than for sales taxes.

An omission in the literature is the absence of analysis on the elasticity of charges and fees. Charges and fees are now the largest single revenue source for state and local governments in many states (McCubbins and Moule 2009). In this paper we replicate the aforementioned results on the income-elasticity of tax revenue sources, and present new results on the elasticity of charges and fees and property taxes.

We rely on the method described by Holcombe and Sobel (1997) to estimate the short-run elasticity of state and local revenue sources. For this analysis we use data from the Department of Commerce on aggregate state and local revenue components from 1963-2005. This dataset includes a breakdown of state and local revenues into sales taxes, personal income taxes, corporate income taxes, property taxes, and other revenue sources, nationwide. This last category includes motor vehicle license taxes, other taxes, charges and fees, and miscellaneous revenues. All variables are transformed to constant dollars using the consumer price index.

Optimally, to estimate income elasticity it is best to have data on tax bases, not tax revenues. As explained by Holcombe and Sobel, elasticity estimates will be biased if policy decisions to raise or lower taxes are correlated with economic changes. Though this is a consideration in our analysis, Holcombe and Sobel's own estimates show that there is a strong correlation between estimates derived from tax bases and tax revenues. Further, it would be difficult, if not impossible, to estimate the "tax base" from which charges and fees are drawn. As such we follow previous analysis, including Box, Fox, and Tuttle (2006), and estimate the income 
elasticity of actual revenues.

Holcombe and Sobel (1997) develop an error correction model to estimate short-run income elasticity described by (2):

$$
\Delta \ln \left(R_{t}\right)=\alpha+\beta_{1} \Delta \ln \left(I_{t}\right)+\beta_{2}\left(\mathrm{E}_{t-1}\right)+\varepsilon
$$

Where $\mathrm{R}_{\mathrm{t}}$ is the time-series of a revenue component, $\mathrm{I}_{\mathrm{t}}$ is the time-series of state personal income, and $\mathrm{E}_{\mathrm{t}}$ is a variable used for error-correction. As described by Holcombe and Sobel, error correction is necessary in the estimation of short-run elasticity because "Two non-stationary variables that have a long-run relationship with one another will tend to move back together whenever they get too far apart (a regression to their mean relationship). Thus one may observe one variable moving down in the same period another is moving up simply because the variables deviated from the levels implied by their long-run relationship" (Holcombe and Sobel 1997, p 83). Here, the error correction variable is the lagged residual derived from an estimate of long-run elasticity (see Sobel and Holcombe 1997).

Table 4 presents the short-run income-elasticity estimates of the major components of state and local revenue. These coefficients represent the percentage change in the revenue component associated with a one percent change in state personal income. The results largely confirm the analysis by Holcombe and Sobel. Corporate income tax revenue has the highestelasticity, varying by 2.83 percentage points for every one percent change in total state personal income. This result is graphed in Figure 2. Changes in corporate income tax revenues follow roughly, and magnify nearly three-fold, changes in personal income. The results for personal income taxes are very similar, with an income-elasticity of 2.17 . 
Table 4

An Error Corection Model of Short-Run Income Elasticity, 1963-2005

\begin{tabular}{ll}
\hline Regression Coefficients of Short-Run Income \\
\hline Corporate Income Tax & $2.83(0.52)^{* * *}$ \\
Personal Income Tax & $2.17(0.31)^{* * *}$ \\
Charges and Fees & $1.06(0.15)^{* * *}$ \\
Sales Tax & $0.93(0.13)^{* * *}$ \\
Property Tax & $0.12(0.16)$ \\
\hline
\end{tabular}

Note: Estimates from a regression of changes of logged personal income on changes of logged revenue sources. Error correction from long-run elasticity estimates are employed. Analysis uses Commerce Department data of state and local government revenues (constant dollars) and BEA annual estimates of national personal income (constant dollars) from 1963-2005. $R$-squareds range from 0.07 (property taxes) to 0.59 (pesonal income taxes). * signifies that the coefficient is significant at the .1 confidence level; ** at the .05 level; and *** at the .01 level.

Table 4 also shows that receipts from "other" sources, largely charges and fees, have elasticity greater than one. Again, this level of elasticity means that this revenue source will fluctuate more than the general economy. The income-elasticity of charges and fees is not surprising given what we know about consumer behavior during recessions. As the most recent Census data shows, recessions stop consumers from getting married, moving, immigrating, and a variety of other behaviors associated with government fees for services. Revenues from impact fees, charges paid by real-estate developers for development projects, certainly slow or can even cease during downturns. If citizens are not paying as much charges and fees during recessions, revenues will go down even when costs for the government are fixed. The elasticity of charges and fees is graphed against income in Figure 3. Again, as supported by the regression data, this revenue source matches and magnifies changes in the economy. 
Figure 2

Income-Elasticity of Corporate Income Taxes

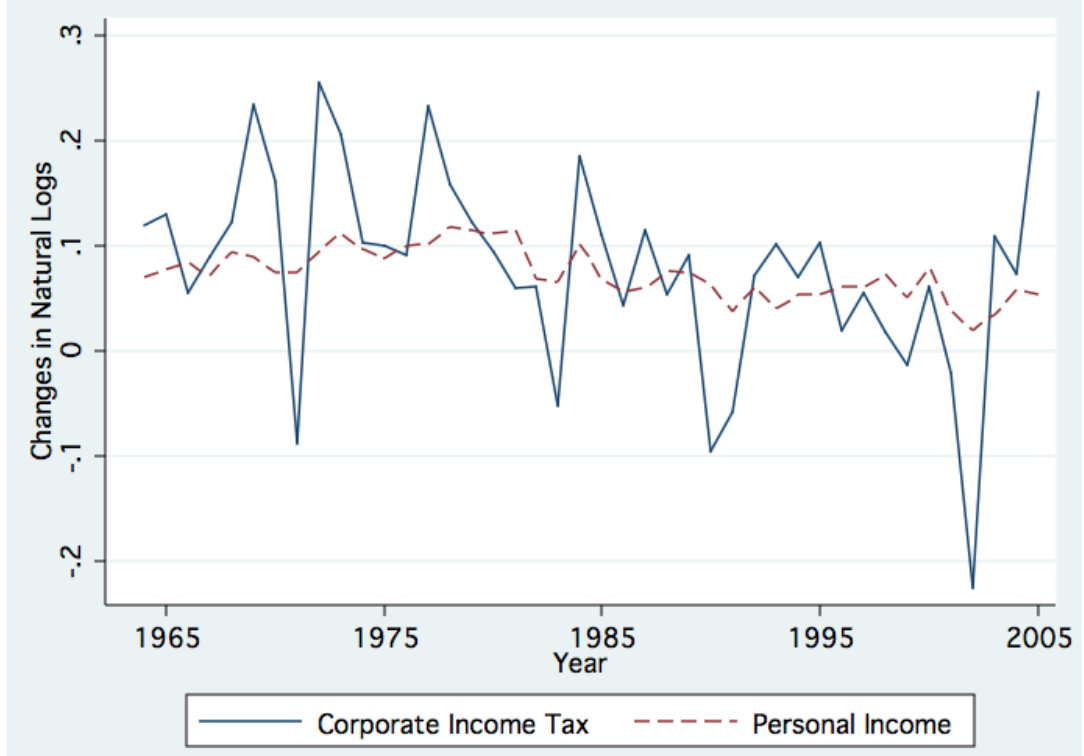

Figure 3

Income-Elasticity of Charges and Miscelaneous Revenues

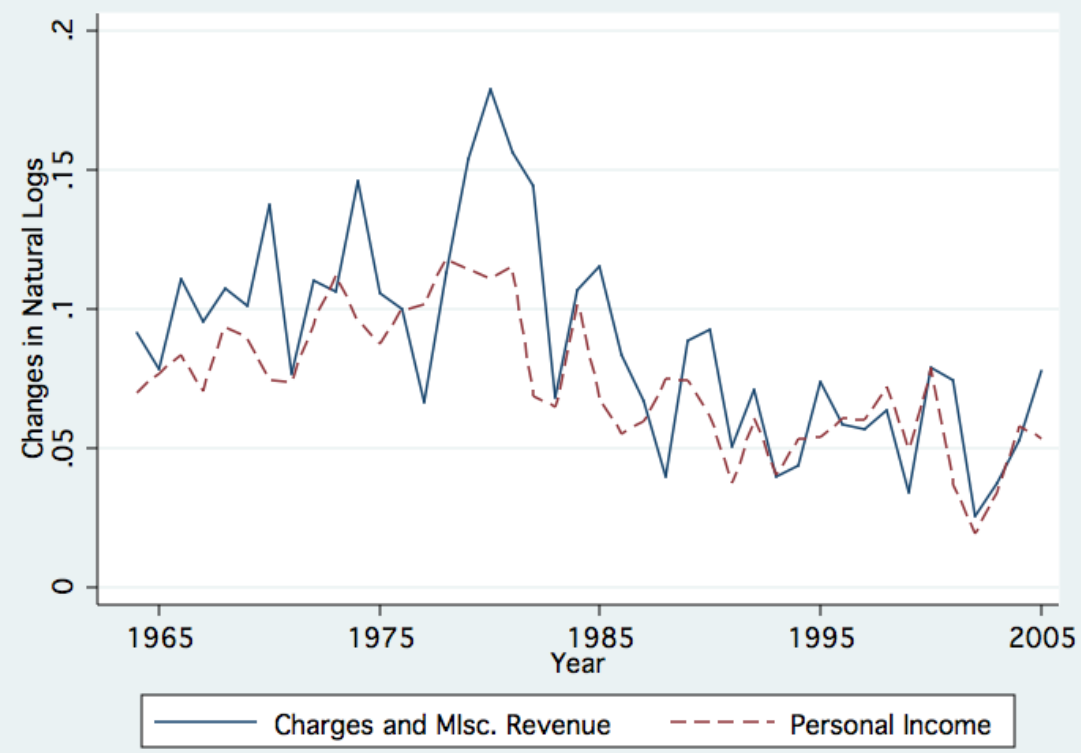

We also confirmed through this analysis that property tax revenues are highly incomeinelastic. Of the five revenue sources analyzed herein, property taxes are the only source of revenue that is not significantly predicted by changes in personal income. Figure 4 plots the 
change in log state and local property tax revenue with the change in log personal income. As evident from the figure, property tax revenues often appear almost counter-cyclical.

Figure 4

Income-Inelasticity of Property Taxes

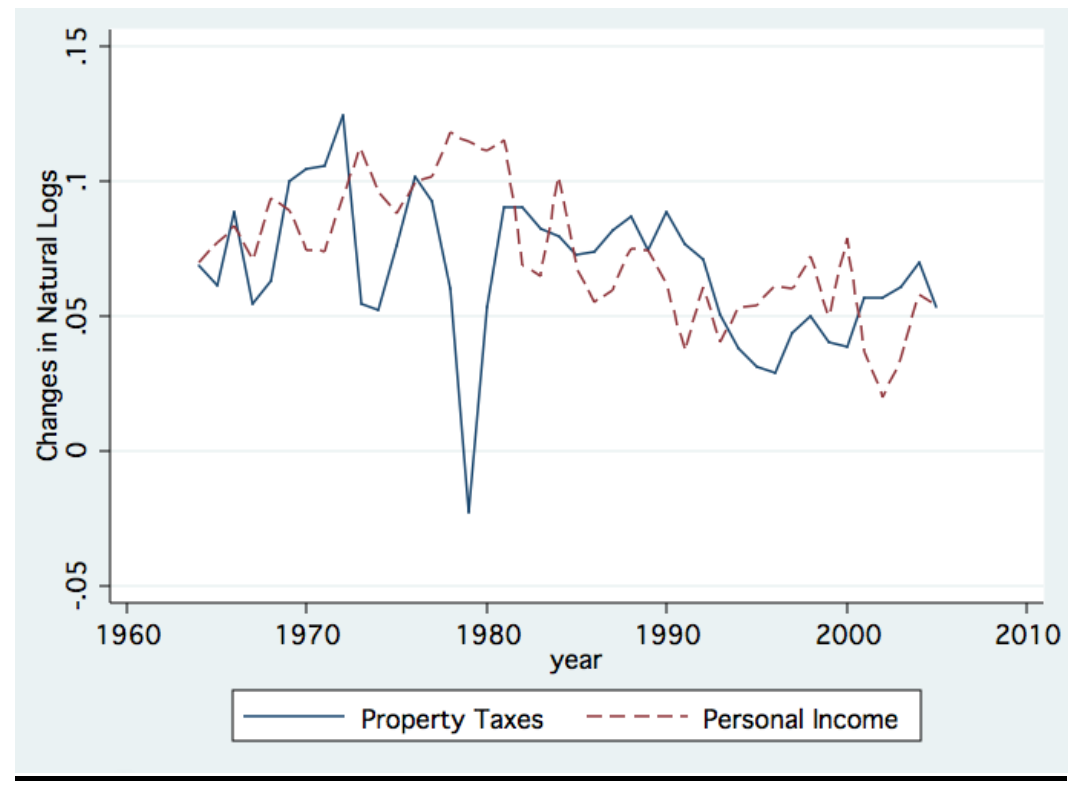

The important lesson from this analysis is that some revenues will be more stable than others during times of fiscal crisis. Although the most recent fiscal crisis was precipitated by falling home prices, historically property values are stable during downturns. Moving away from property taxes to more elastic forms of revenue, such as the charges and fees or income tax, could make states more susceptible to cyclical volatility. This danger was recognized by Holcombe and Sobel who noted that, "If the trend away from local reliance on property taxes continues, however, local governments may not be as insulated from recessionary fiscal crisis in the future." (Holcombe and Sobel 1997, p. 51)

The consequence of increased elasticity after adoption of a property tax limit is particularly clear in the case of Oregon. Although Oregon officially had a binding property tax limit in place at 
the beginning of our time series (it passed a levy-limit of 106\% growth starting in 1916), Oregon passed additional limitations in 1990, 1996, and 1997 (the 1996 limit was never implemented). The change in revenue policy before and after 1990 has particularly noticeable implications for elasticity. Prior to 1990, Oregon had a levy-based system of calculating property taxes. Local governments passed a budget and deducted the amount of state aid from the total. The remaining revenue requirement would determine that year's property tax rate. The anti-cyclical behavior of this system, as noted by Thompson and Greene (2004), is that the level of tax burden from year to year was highly dependent on state aid. As noted by Thompson and Greene (2004), "fluctuations in state school aid were not random; the state legislature tended to increase funding during economic upswings and cut it during recessions, thereby exacerbating the local property tax's bite." (Thompson and Greene 2004, p. 75). The adoption of the 1990 property tax limit eliminated the property tax as a revenue safety net during recessions. Oregon's revenues have become far more income-elastic following the adoption of this limit (Thompson and Greene 2004).

\section{Property tax limits and Recessions}

We turn now to our central analysis, the affect of property tax limits during recessions. In this section we test whether property tax limits aggravate revenue declines during fiscal downturns. We rely on indicators from Owyang, Piger, and Wall (2005) for statewide recessions. The Owyang, Piger, and Wall (2005) data is a significant improvement to previous research that simply relied on national-level recession data. As shown by Owyang, Piger, and Wall (2005), there is tremendous variation between states regarding business cycles. This finding is not 
surprising given the diverse economies of the fifty states. Using this data we are able to take advantage in the rich variation in state business cycles to produce more accurate estimates of their effects.

We estimate the affect of property tax limits, recessions, and their interactions on state and local general, own-source revenue using differences-in-differences. As previously mentioned, this model holds constant trends common to states over time as well as unobserved, time-invariant state-level characteristics. We do, of course, sweep many of the requirements for the Stable Unit Treatment Value Assumption (SUTVA), such as unconfoundedness, under the rug, however. We estimate the following equation:

$$
\Delta y_{j t}=\beta_{0}+\beta_{1} \mathrm{~T}_{i t}+\beta_{2} \Psi_{i t}+\beta_{3} \mathrm{~T} * \Psi_{i t}++\beta_{4} \Delta \theta_{i t}+\beta_{5} \gamma_{i t}+a_{i}+\kappa_{t}+u_{i t}
$$

Where:

$\mathrm{y}=$ fiscal outcome

$\mathrm{T}=$ indicator a tax limit

$\psi=$ indicator of a recession

$\theta=$ Population and Economic Covariates

$\mathrm{Y}=$ Political Covariates

$\kappa=$ Year fixed effects

$\lambda=$ State fixed effects

All continuous variables are log-transformed and first-differenced. This specification is common with econometric data, particularly in the study of short-term effects of fiscal crisis. First-differencing is particularly helpful in eliminating autocorrelation. However, because the Breuch-Pagan Test for residual autocorelation was affirmative, we also employ a lag dependent variable, as suggested by Beck and Katz (2009). Removing serial correlation is important to our analysis because, as noted by Bertrand, Duflo, and Mullainathan (2003), serial correlation often causes one to underestimate standard errors in differences-in-differences estimation leading to 
mistaken rejection of the null hypothesis. Indeed, from a series of simulations, those authors found effects "significant at the 5 percent level for up to 45 percent of the placebo interventions.” (Bertrand, Duflo, and Mullainathan 2003, 1).

The coefficients of our model are interpreted as effects on state and local general, ownsource revenue growth rates. Our results are presented in Table 5. We present two models of our results, the second excluding the continuous economic variables as they are highly correlated with the recession indicators. Here we report the results for the first model. We find that both elderly and school-age population variables are insignificant, but that that a one percentage point change in total population leads to a 2.1 percentage change in the growth of general, own-source revenues. Unified Republican and Democratic control of state government has the expected, although only weakly-significant effects on revenue growth, increasing growth during unified Democratic control and decreasing growth during unified Republican control. The inclusion of economic variables in Model 2 has negligible effects on these findings. 


\section{Table 5}

The Effect of Recession and Tax Limits on Revenue

\begin{tabular}{lll}
\hline & \multicolumn{2}{l}{$\Delta$ LN General Revenue } \\
& Model 1 & Model 2 \\
\hline Lag DV & $-0.146(0.064)^{* *}$ & $-0.151(0.064)^{* *}$ \\
$\Delta$ LN School-Age Population & $-0.071(0.207)$ & $-0.023(0.204)$ \\
$\Delta$ LN Elderly Population & $-0.411(0.308)$ & $-0.404(0.305)$ \\
$\Delta$ LN Total Population & $2.119(0.345)^{* * *}$ & $1.971(0.449)^{* * *}$ \\
$\Delta$ LN Total Employment & & $-0.036(0.156)$ \\
$\Delta$ LN Personal Income & & $0.149(0.094)$ \\
Unified Democratic Control & $0.006(0.004)^{*}$ & $0.006(0.004)^{*}$ \\
Unified Republican Control & $-0.005(0.003)^{*}$ & $-0.005(0.002)^{* *}$ \\
Recession X Limit & $-0.003(0.002)^{* *}$ & $-0.003(0.001)^{* *}$ \\
Property Tax Limit & $0.006(0.004)$ & $0.006(0.004)$ \\
Fixed Effects & included & included \\
Year Effects & included & included \\
Recession & $-0.012(0.004)^{* * *}$ & $-0.010(0.004)^{* *}$ \\
Constant & $0.0375(0.010)^{* * *}$ & $0.032(0.010)^{* * *}$ \\
\hline Number of Obs. & 1029 & 1029 \\
R-Squared & 0.396 & 0.401 \\
\hline
\end{tabular}

Note: Panel Corrected Standard Errors in parentheses. 49 states, Alaska excluded. Years Covered: 1980-2000. * signifies that the coefficient is significant at the .1 confidence level; ** at the .05 level; and *** at the .01 level.

The most important independent variables in this model are the affects of tax limits, recessions, and their interaction of the two on revenue growth rates. The results suggest that property-tax limits, in absence of a recession, have no affect on general revenue growth. This finding replicates the findings in our previous research (Kousser, McCubbins, Moule 2008). However, new to this paper is the finding that property tax limits do in fact have significant affects on revenue during recessions. ${ }^{3}$ The interaction variable suggests that in the presence of a recession, a tax limit would decrease state and local own-source general revenue by an additional 0.3 percent. This result is significant at the 5 percent level. This decline should be interpreted

\footnotetext{
${ }^{3}$ This result is also consistent with the possibility that Property tax limits themselves are binding only during recessions. This alternative hypothesis has some anecdotal evidence to support it, and is a reasonable possibility given the fact that many property tax limits are tied directly to an index of economic indicators, such as growth in personal income or the inflation rate (Poterba and Reuben 1996, National Council of State Legislatures 2009). We do not reject the possibility that this is an additional mechanism by which property tax limits reduce revenues during recessions.
} 
cumulatively with the overall affect of recessions, which adds an additional 1.2 percent decline in revenue. States that enact property tax limitations fare much worse than states without limits during recessions. Given likely heterogeneity of the effectiveness of property tax limits, these results are likely underestimate the effect of these limits.

\section{Conclusion}

We have demonstrated that property tax limits have negative effects on state and local revenues during fiscal crises. Property limits cause states to rely on income-elastic revenue sources, such as the income tax or charges and fees. The consequence of this substitution is apparent when you look at how these revenues are differentially affected by the economy. For many years, property taxes were a highly inelastic form of revenue, a source of stability in the face of personal income declines. Greater reliance on an income-elastic revenue source will result in greater revenue declines during economic downturns. This was shown in the negative and significant interaction effect between the recession indicator and property tax limits.

Our results suggest that states, in response to tax limits, are builidng a revenue system that puts them on a budgetary roller-coaster with huge swings between the apex of the coaster's climb and the nadir of its fall. As it seems unlikely that politicians will choose to limit spending during the good times, and so far attempts to adopt strict Rainy Day Funds have been limitted.

Scholars of the origin of California's Proposition 13 have long-time identified the highly progressive, and thus income-elastic, state income taxes as an immediate cause of the property tax limit. The economic boom of the late 1970s prompted high taxes and large surpluses. Paradoxically, as this paper has shown, the passage of the property tax limit only aggravates the problem of elastic revenues. It is ironic that heavier reliance in income-elastic revenues will, in 
the long-term, have the opposite affect of the tax reformer's intentions. In the long term, incomeelastic revenue sources grow at rates higher than the economy itself. This means that it is plausible that tax reforms have actually set the course for the higher growth of government. 


\section{REFERENCES}

Alt, James E. and Robert C. Lowry, 1994.

"Divided Government, Fiscal Institutions, and Budget Deficits: Evidence from the States." American Political Science Review 88(December), 811-828.

Alt, James E. and Robert C. Lowry, 2000.

"A dynamic model of state budget outcomes under divided partisan government." Journal of Politics 62(4), 1035-70.

Beck, Nathaniel and Jonathan N. Katz, 1995.

"What to Do (and Not to Do) With Time-Series Cross-Section Data." American Political Science Review 89 (3), 634-647.

Bennett, James T. and Thomas J. Dilorenzo, 1982.

"Off-budget activities of local government: The bane of the tax revolt." Public Choice 39(3), 333342.

Bowler, Shaun, and Todd Donovan, 2004.

"Evolution in State Governance Structures: Unintended Consequences of State Tax and Expenditure Limitations." Political Research Quarterly 57 (2):189-96.

Bruce, Donald, William F. Fox, and Mark H. Tuttle, 2006.

"Tax Base Elasticities: A Multi-State Analysis of Long Run and Short Run Dynamics." Southern Economic Journal 73(2), 315-341.

Crone, T. M., 2002.

"Consistent Economic Indexes for the 50 States." Federal Reserve Bank of Philadelphia working paper no. 02-7. Federal Reserve Bank of Philadelphia, Philadelphia, PA.

Danziger, James N. and Peter Smith Ring, 1982.

"Fiscal Limitations: A Selective Review of Recent Research." Public Administration Review 42(1), $47-55$.

Gerber, Elisabeth R., Arthur Lupia, Mathew D. McCubbins, and D. Roderick Kiewiet, 2001. Stealing the Initiative: How State Government Responds to Direct Democracy. Upper Saddle River, NJ: Prentice Hall.

Hamilton, J. D., 1989.

"A New Approach to the Economic Analysis of Nonstationary Time Series and the Business Cycle," Econometrica 57(2), 357-384.

Holcombe, Randall G., and Russell S. Sobel, 1997.

Growth and Variability in State Tax Revenue: An Anatomy of State Fiscal Crises. Westport, CT:

Greenwood Press.

Joyce, Philip G., and Daniel R. Mullins, 1991.

"The Changing fiscal Structure of the State and Local Public Sector: The Impact of Tax and Expenditure. Public Administration Review 51(3): 240-253.

Kiewiet, D. Roderick and Kristin Szakaly, 1996. 
"Constitutional Limitations on Borrowing: An Analysis of State Bonded Indebtedness." The Journal of Law, Economics, and Organization 12:62-97.

Kogan, Vladamir, and Mathew D. McCubbins, 2009.

“The Problem With Being Special.” Public Works Management \& Policy, 14(1), 4-36.

Kousser, Thad, Mathew D. McCubbins, and Ellen Moule, 2008.

"For Whom the TEL Tolls: Can State Tax and Expenditure Limits Effectively Reduce Spending?" . State Politics and Policy Quarterly 8(4), 331-361.

Lewis, Paul G., 2001.

"Retail Politics: Local Sales Taxes and the Fiscalization of Land Use". Economic Development Quarterly 15(1), 21-35.

McCubbins, Mathew D. and Ellen Moule, 2009.

"The Fiscal Shape of the American States: Trends and Issues in State Budgeting in the 21st Century" (Special report for Governing Arizona, a program of the Thomas R. Brown Foundations and The Communications Institute.

Moule, Ellen, 2010.

The General Equilibrium of Tax and Expenditure Limits. Ph.D. dissertation. University of California, San Diego. San Diego, CA.

Mullins, Daniel R. and Philip G. Joyce, 1996.

"Tax and Expenditure Limitations and State and Local Fiscal Structure: An Empirical Assessment." Public Budgeting and Finance 16(1), 75-101.

National Council of State Legislatures, 2009.

"State Tax and Expenditure Limits." http://www.ncsl.org.

Owyang, Michael T., Jeremy Piger, and Howard J. Wall, 2005.

"Business Cycle Phases in the US States." The Review of Economics and Statistics 87(4), 604616.

Poterba, James M. and Kim S. Rueben, 1999.

Fiscal Rules and State Borrowing Costs: Evidence from California and Other States. San

Francisco, CA: Public Policy Institute of California.

Schwartz, J., 1997.

"Prisoners of Proposition 13: Sales taxes, property taxes, and the fiscalization of municipal land use decisions." Southern California Law Review 71, 183-217.

Skidmore, Mark, 1999.

"Tax and expenditure limitations and the fiscal relationships between state and local governments." Public Choice 99(1-2), 77-102.

Stock, J. H., and M. W. Watson, 1989.

"New Indexes of Coincident and Leading Economic Indicators," NBER Macroeconomics Annual 4, 351-393.

Thompson Fred and Green M., 2004.

"Vox Populi?: Oregon Tax and Expenditure Limitation Initiatives." Public Budgeting and Finance $24(1), 73-87$. 
Wooldridge, Jeffrey, 2006.

Introductory Econometrics: A Modern Approach. South-Western College Publishing.

Zellner, A., 1962.

"An Efficient Method of Estimating Seemingly Unrelated Regressions and Tests for Aggregation Bias." Journal of the American Statistical Association 57 (1), 348-368. 